\title{
Validated Method for the Determination of Gemifloxacin in Bulk, Pharmaceutical Formulations and Human Serum by RP-HPLC: In Vitro Applications
}

\author{
Najma Sultana, ${ }^{a}$ M. Saeed Arayne, ${ }^{b}$ Sana Shamim, ${ }^{* a}$ Mahwish Akhtar ${ }^{a}$ and Somia Gul ${ }^{a}$ \\ ${ }^{a}$ Research Institute of Pharmaceutical Sciences, Department of Pharmaceutical Chemistry, Faculty \\ of Pharmacy and ${ }^{b}$ Department of Chemistry, University of Karachi, Karachi-75270, Pakistan
}

\begin{abstract}
Um método isocrático de cromatografia líquida de alta resolução de fase reversa (RP-HPLC) foi desenvolvido para determinação de gemifloxacin a granel, em formulações e soro humano a $270 \mathrm{~nm}$. A separação cromatográfica foi adquirida em uma coluna Purospher STAR $C_{18}(250 \times 4,6 \mathrm{~mm}$, $5 \mu \mathrm{m})$ usando a fase móvel metanol:água $(90: 10, \mathrm{v} / \mathrm{v})$ ajustada para $\mathrm{pH} 2,8 \mathrm{com}$ ácido fosfórico $85 \%$ em fluxo de $1,5 \mathrm{~mL} \mathrm{~min}^{-1}$ a temperatura ambiente. As curvas de calibração mostraram-se lineares dentro do intervalo de 5-100 $\mu \mathrm{g} \mathrm{mL}^{-1}$ com um coeficiente de correlação de 0,9998 . Os limites de detecção (LOD) e de quantificação (LOQ) foram 0,015 and $0,045 \mu \mathrm{g} \mathrm{mL} \mathrm{mL}^{-1}$, respectivamente. Os resultados de precisão intra- e inter-corridas e de exatidão foram 98,73-100,12\%, que foram correlacionados através do teste t student. Este método foi aplicado para interações in vitro do gemifloxacino com elementos essencial e traço.
\end{abstract}

An isocratic reversed phase high-performance liquid chromatographic (RP-HPLC) method has been developed for the determination of gemifloxacin in bulk, dosage formulations and human serum at $270 \mathrm{~nm}$. Chromatographic separation was achieved on Purospher STAR C ${ }_{18}(250 \times 4.6 \mathrm{~mm}$, $5 \mu \mathrm{m})$ column using mobile phase methanol:water (90:10, v/v) adjusted $\mathrm{pH} 2.8$ via phosphoric acid $85 \%$ having flow rate of $1.5 \mathrm{~mL} \mathrm{~min}^{-1}$ at ambient temperature. Calibration curves were linear over range of 5-100 $\mu \mathrm{g} \mathrm{mL}^{-1}$ with a correlation coefficient 0.9998 . The limit of detection (LOD) and limit of quantitation (LOQ) were 0.015 and $0.045 \mu \mathrm{g} \mathrm{mL} \mathrm{L}^{-1}$, respectively. Intra and inter-run precision and accuracy results were $98.73-100.12 \%$ and then correlated through student's $t$-test. This method was further applied for in vitro interactions of gemifloxacin with essential and trace elements.

Keywords: gemifloxacin, HPLC, human serum, student's $t$-test

\section{Introduction}

Gemifloxacin (GMFX) is a fourth generation fluoroquinolone antibacterial compound with enhanced affinity for bacterial topoisomerase IV and is being used for the treatment of respiratory and urinary tract infections. The compound has a broad spectrum of activity against Grampositive and Gram-negative bacteria. ${ }^{1-3}$ It is particularly active against Gram-positive organisms including penicillin, macrolide, and quinolone resistant Streptococcus pneumoniae ${ }^{4} 4$-folds more potent than moxifloxacin against $S$. pneumoniae. ${ }^{5}$ Gemifloxacin has also shown potent activity against other major pathogens involved in respiratory tract infections, including Haemophilus influenzae and Moraxella catarrhalis and the atypical

*e-mail: ssanashamim@yahoo.com organisms, Legionella pneumophila, Chlamydia spp. and Mycoplasma spp. ${ }^{6,7}$ Furthermore, the compound has shown potent activity against many organisms that cause urinary tract infections and bronchitis. ${ }^{8}$

Literature survey revealed that few analytical methods have been reported for the estimation of GMFX, they include high performance liquid chromatography tandem mass, ${ }^{9,10}$ microchip electrophoresis, ${ }^{11}$ chiral highperformance liquid chromatography ${ }^{12}$ and chiral countercurrent chromatography. ${ }^{13,14}$ Simple and sensitive ionpairing spectrophotometer methods have been described for the assay of gemifloxacin mesylate by Marothu et al..$^{15}$ Barbosa and co-workers ${ }^{16}$ studied dissociation constants of series of compounds including diuretics and quinolones in several acetonitrile:water mixtures.

The aim of the present study was to establish an efficient, reliable, accurate, sensitive and reproducible 
method for the quantitative determination of gemifloxacin. As this would allow more efficient generation of clinical data and could be performed at more modest cost.

\section{Experimental}

\section{Chemicals and reagents}

All chemicals and reagents were of analytical grade with purity percentage $99.89 \%$. Gemifloxacin was a kind gift from Pharm Evo (Pvt) Ltd., Pakistan. Figure 1 shows the chemical structure of gemifloxacin mesylate. HPLC grade methanol was obtained from Merck Schuchardt OHG (Darmstadt, Germany). Each product was labeled and expiry dates were not earlier than two years, at the time of study. HPLC grade methanol were supplied by Tedia company, INC. (USA).

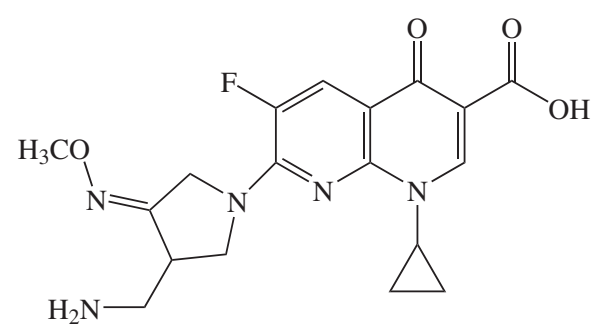

Figure 1. Chemical structure of gemifloxacin mesylate.

The essential and trace elements used were of analytical grade in the form of their hydrated salts as magnesium chloride hexahydrate $\left(\mathrm{MgCl}_{2} \cdot 6 \mathrm{H}_{2} \mathrm{O}\right)$, calcium chloride dehydrate $\left(\mathrm{CaCl}_{2} \cdot 2 \mathrm{H}_{2} \mathrm{O}\right)$, chromium chloride hexahydrate $\left(\mathrm{CrCl}_{3} \cdot 6 \mathrm{H}_{2} \mathrm{O}\right)$, manganese chloride tetrahydrate $\left(\mathrm{MnCl}_{2} \cdot 4 \mathrm{H}_{2} \mathrm{O}\right)$, ferric chloride hexahydrate $\left(\mathrm{FeCl}_{3} \cdot 6 \mathrm{H}_{2} \mathrm{O}\right)$, cobalt chloride hexahydrate $\left(\mathrm{CoCl}_{2} \cdot 6 \mathrm{H}_{2} \mathrm{O}\right)$, nickel chloride hexahydrate $\left(\mathrm{NiCl}_{2} \cdot 6 \mathrm{H}_{2} \mathrm{O}\right)$, copper chloride dehydrate $\left(\mathrm{CuCl}_{2} \cdot 2 \mathrm{H}_{2} \mathrm{O}\right)$, zinc chloride $\left(\mathrm{ZnCl}_{2}\right)$ and cadmium chloride monohydrate $\left(\mathrm{CdCl}_{2} \cdot \mathrm{H}_{2} \mathrm{O}\right)$, lead carbonate $\left(\mathrm{PbCO}_{3}\right)$, arsenic oxide $\left(\mathrm{Ar}_{2} \mathrm{O}_{3}\right)$, silver chloride $\left(\mathrm{AgCl}_{3}\right)$, purchased from E-Merck (Germany).

Concerning the pharmaceutical dosage form, Gemixa ${ }^{\mathrm{TM}}$ (Gemifloxacin $320 \mathrm{mg}$ tablets by Bosch Pharmaceuticals (Pvt Ltd.)) was purchased from the local pharmacy. Expiry dates were not earlier than two years, at the time of study.

\section{Statistical study}

Standard regression curve analysis was performed by use of STATISTICA version 7.0 (USA), without forcing through zero. Linearity graphs were obtained by use of Microsoft Excel 2007 software. SPSS software version 10.0 (Carry, NC, USA) was used for the calculation of means, standard deviations, homoscedasticity of the calibration plots and Student's $t$-test.

\section{Instrumentation}

The UV-Vis spectrophotometer (Shimadzu 1601), integrated with a P IV computer loaded with UVPC version 3.91 was used to optimize the wavelength. The HPLC system consisted of an LC-20 AT VP Shimadzu pump and SPD-20AV VP Shimadzu UV-Vis detector, and the separation was achieved on a Purospher STAR $\mathrm{C}_{18}(250 \times 0.46 \mathrm{~mm}, 5 \mathrm{~mm})$. The chromatographic and integrated data were recorded using a CBM-102 communication Bus Module Shimadzu. Sonicated by DGU-14 AM, and filtered through 0.45-micron membrane filter. Calibrated Pyrex glassware was used for the solution and mobile phase preparation

\section{Calibration standards and quality control samples}

\section{Standard preparation}

Calibration standard solutions of GMFX were prepared by dissolving $1 \mathrm{mg} \mathrm{mL}^{-1}$ of drug using mobile phase as solvent and kept in $100 \mathrm{~mL}$ of volumetric flasks. Working solutions were prepared separately by making serial dilutions from the standard solution to obtain concentration between $5-100 \mu \mathrm{gL}^{-1}$ for GMFX. For quality control samples (QC), twenty tablets of gemifloxacin were powdered finely and an amount equivalent to $10 \mathrm{mg}$ of GMFX was weighed and then dissolved in the mobile phase. Solutions with high, medium and low concentrations, i.e. 40, 50 and $60 \%$ were prepared, and then filtered through a $0.45 \mu \mathrm{m}$ Millipore filter, in order to separate out the insoluble excepients by the same procedure as calibration standards but using different stock solutions.

All these solutions, calibration and QC were stored at $20^{\circ} \mathrm{C}$. Once prepared, analyzed daily for inter and intraday variations of the method. $20 \mu \mathrm{L}$ of these solutions were injected into LC system and chromatographed

\section{Procedure for human serum}

Plasma sample, obtained from healthy volunteers, was collected and stored at $-20{ }^{\circ} \mathrm{C}$. To an aliquot of $1.0 \mathrm{~mL}$ plasma, $10 \mathrm{~mL}$ of acetonitrile was added and the mixture was vortexed for $1 \mathrm{~min}$ followed by centrifugation at $10,000 \mathrm{rpm}$ during $10 \mathrm{~min}$. It was then alienated supernatant by filtration $(0.45 \mu \mathrm{m}$ pore size membrane filter). An aliquot 
serum sample was fortified with gemifloxacin to get the final concentrations of 5-100 $\mu \mathrm{g} \mathrm{mL}^{-1}$.

\section{Procedure for in vitro interaction studies}

For interaction study stock solutions of GMFX and metals were prepared by dissolving $10 \mathrm{mg}$ of the drug in $100 \mathrm{~mL}$, using buffers of $\mathrm{pH} 1.0,4.0,7.4$ and 9.0 as solvents, individually, then sonicated. Similarly stock solutions of metal salts $\left(\mathrm{MgCl}_{2} \cdot 6 \mathrm{H}_{2} \mathrm{O}, \mathrm{CaCl}_{2} \cdot 2 \mathrm{H}_{2} \mathrm{O}, \mathrm{CrCl}_{3} \cdot 6 \mathrm{H}_{2} \mathrm{O}\right.$, $\mathrm{MnCl}_{2} \cdot \mathrm{H}_{2} \mathrm{O}, \mathrm{FeCl}_{3} \cdot 6 \mathrm{H}_{2} \mathrm{O}, \mathrm{CoCl}_{2} \cdot 6 \mathrm{H}_{2} \mathrm{O}, \mathrm{NiCl}_{2} \cdot 6 \mathrm{H}_{2} \mathrm{O}$, $\mathrm{CuCl}_{2} \cdot 2 \mathrm{H}_{2} \mathrm{O}, \mathrm{ZnCl}_{2}$ and $\mathrm{CdCl}_{2} \cdot \mathrm{H}_{2} \mathrm{O}$ ) were prepared in the same concentrations gemifloxacin solution and mixed with solution of metal in a flask. The final concentration of these solution was $50 \mu \mathrm{g} \mathrm{mL}^{-1}$ and the their flasks were then kept in water bath at $37 \pm 5^{\circ} \mathrm{C}$ for $3 \mathrm{~h}$. Aliquots of $5 \mathrm{~mL}$ were withdrawn at an interval from 30 to $180 \mathrm{~min}$, following filtration through normal filter paper then $0.45 \mu \mathrm{m}$ filter paper to avoid any hindrance and then subjected to assay by RP-HPLC. Same procedure was repeated with heavy metals (lead $\left(\mathrm{PbCO}_{3}\right)$, arsenic $\left(\mathrm{Ar}_{2} \mathrm{O}_{3}\right)$ and silver $\left(\mathrm{AgCl}_{3}\right)$ ) for interaction study.

\section{Results and Discussion}

\section{Method development}

The aim of the present study was to develop a simple, isocratic, accurate and sensitive HPLC method for the determination of GMFX. Purospher STAR column $\left(\mathrm{C}_{18}(250 \times 0.46 \mathrm{~mm}, 5 \mathrm{~mm})\right)$ provided the best peak shapes and efficiencies. The chromatographic conditions, especially the composition of the mobile phase, were optimized through several trials to achieve symmetric peak shapes for GMFX, as well as shorter run time. It was found that a mobile phase containing a high proportion of methanol gives symmetric peak shape. Therefore the final mobile phase was composed of methanol and water in ratio of 90:10 (v/v) providing good resolution.

In order to keep constant $\mathrm{pH}$ of the mobile phase, $85 \%$ phosphoric acid was added into mobile phase to achieve the desire $\mathrm{pH}$. The mobile phase $\mathrm{pH}$ had a little impact on resolution and the best separations were observed at $\mathrm{pH}$ 2.8. The chromatographic conditions were optimized to achieve best separation and to get best resolution between analytes and to optimize chromatographic parameters like resolution, tailing factor and retention time.

Peaks were identified using retention times compared with those of standards. Retention time was 3.8 min for GMFX. For validation of analytical methods, the guidelines of the International Conference on the Harmonization of Technical Requirements for the Registration of Pharmaceuticals for Human Use ${ }^{17}$ and USP $2002^{18}$ were followed for the accuracy tests, precision, specificity, linearity, work strip and robustness of the method.

\section{Method validation}

\section{System suitability}

It is an imperative module of method validation to make certain that the operational system is running appropriately throughout the analysis. The system was equilibrated with the initial mobile phase composition, followed by 10 injections of the same standard. These 10 consecutive injections were used to evaluate the system suitability on each day of method validation (Table 1).

\section{Calibration curves}

Calibration curves were characterized by different linear segments. These curves were obtained using the linear least squares regression procedure. These analysis results reveal good linear correlations (Table 1). The homoscedasticity of the calibration plots, tested by Friedman's tests, were found to be significantly linear over the tested ranges.

\section{Recovery studies}

The accuracy of the method was evaluated from the recovery results of spiked placebo samples. Appropriate portions of stock solution of drugs were spiked into blank placebo matrix to produce concentrations of 40, 50 and $60 \mu \mathrm{g} \mathrm{mL}-1$ of the theoretical concentration. Mean recovery

Table 1. Regression and system suitability characters

\begin{tabular}{|c|c|c|c|c|c|c|c|}
\hline Drug & $r^{2}$ & S. E. E. & S.E. & Intercept & $\begin{array}{c}\text { Regression } \\
\text { equation }\end{array}$ & $\begin{array}{c}\text { LOD } \\
\left(\mu \mathrm{g} \mathrm{mL}^{-1}\right)\end{array}$ & $\begin{array}{c}\text { LOQ } \\
\left(\mu \mathrm{g} \mathrm{mL}^{-1}\right)\end{array}$ \\
\hline \multirow[t]{3}{*}{ GMFX } & 0.9998 & 1.87 & 1.12 & 1.34 & $\begin{array}{c}\mathrm{Y}=11536 \mathrm{X}- \\
14539\end{array}$ & 0.015 & 0.045 \\
\hline & $\begin{array}{l}\text { Retention time } \\
\left(\mathrm{t}_{\mathrm{R}}\right)\end{array}$ & $\begin{array}{c}\text { Capacity factor } \\
\left(\mathrm{K}^{\prime}\right)\end{array}$ & $\begin{array}{l}\text { Theoretical plates } \\
\text { (N) }\end{array}$ & $\begin{array}{c}\text { Tailing Factor } \\
\text { (T) }\end{array}$ & $\begin{array}{l}\text { Resolution } \\
\quad\left(\mathrm{R}_{\mathrm{s}}\right)\end{array}$ & & \\
\hline & 5.89 & 4.39 & 2258 & 1.91 & 2.58 & & \\
\hline
\end{tabular}

GMFX = gemifloxacin, S. E. E. = standard error of the estimate and S.E. = standard error. 
of spiked samples were in the ranges of $98.73-100.12 \%$. Recovery tests were performed by adding known amounts of standard solutions to sample followed by analysis using proposed method. Three runs were performed for every concentration and then peak area was calculated (Table 2). The average recovery for each level was calculated as indicated by Association of Official Analytical Chemists International. ${ }^{19-22}$

\section{Precision}

Instrumental precision was determined by six replicate determinations of standard solution, i.e. repeatability. Method precision or intra-assay precision was performed by preparing six different samples involving different weightings. Each solution was injected in triplicate under the same conditions and the mean values of peak area responses for each solution were taken. The precision of the method was analyzed as \%RSD throughout the linear range of concentrations (Table 2). ${ }^{19-22}$ All the results were correlated and found insignificant by student's $t$-tests indicating no remarkable difference in intra and inter day precision.

\section{Specificity and selectivity}

Figure 2 showed the typical chromatograms of drugs alone and with spiked plasma samples. No significant interference was observed from endogenous substances in drug free human plasma at the retention time of all drugs under study.

\section{Ruggedness}

The ruggedness of the method was established by determining GMFX, in bulk, dosage formulation and in human serum in two different laboratories (lab). Lab 1 was Research Institute of Pharmaceutical Sciences,

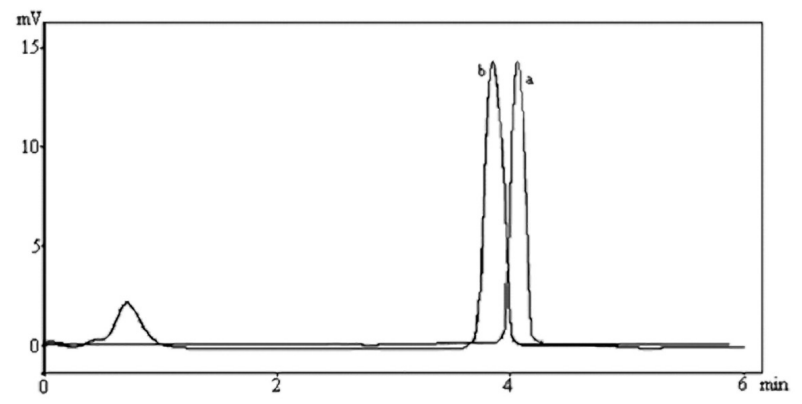

Figure 2. Representative chromatogram of gemifloxacin (GMFX) at a concentration level of $25 \mu \mathrm{g} \mathrm{mL}^{-1}$ in mobile phase (a) composed of methanol:water (90:10, v/v) and human serum (b) at $270 \mathrm{~nm}$.

Department of Pharmaceutical Chemistry, Faculty of Pharmacy, University of Karachi, while other lab was lab 9, Department of Chemistry, Faculty of Science, University of Karachi. For two different instruments at the same configuration, LC 20, on different days and different analytes (Table 2), the results showed to be in good limits.

\section{Robustness}

Robustness of the method was accomplished by designed modifications made to the method parameters, such as $\mathrm{pH}$ of the mobile phase, flow rate and composition. Therefore, five repeated samples were injected under small variations of each parameter. The method proved to be quite stable as there is no considerable drift in the factors as given in Table 3 .

\section{Application of the proposed method for in vitro interaction study}

The interaction study between drugs and transition metals is an important research area in bioinorganic

Table 2. Accuracy and precision of gemifloxacin

\begin{tabular}{|c|c|c|c|c|c|c|}
\hline \multicolumn{7}{|l|}{ Accuracy of gemifloxacin } \\
\hline & \multicolumn{3}{|c|}{ Assay in mobile phase } & \multicolumn{3}{|c|}{ Assay in serum } \\
\hline Conc. Spiked $\left(\mu \mathrm{g} \mathrm{mL} L^{-1}\right)$ & 40 & 50 & 60 & 40 & 50 & 60 \\
\hline Conc. Found $\left(\mu \mathrm{g} \mathrm{mL}^{-1}\right)$ & 39.93 & 49.07 & 60.07 & 39.88 & 49.12 & 60.10 \\
\hline Recovery (\%) & 99.83 & 99.81 & 100.12 & 99.76 & 99.73 & 100.02 \\
\hline \multicolumn{7}{|l|}{ Precision of gemifloxacin } \\
\hline & \multicolumn{2}{|c|}{ Formulation (RSD \%) } & Serum (RSD \%) & \multicolumn{3}{|c|}{$t$-test: paired } \\
\hline Conc. $\left(\mu \mathrm{g} \mathrm{mL} L^{-1}\right)$ & D1 & D2 & D1 & t stat & $\mathrm{df}$ & $\mathrm{T}>\mathrm{t}$ two tailec \\
\hline 5 & 1.009 & 1.013 & 1.011 & -6.528 & 5 & 0.001 \\
\hline 10 & 0.307 & 0.311 & 0.309 & & & \\
\hline 20 & 1.019 & 1.024 & 1.022 & & & \\
\hline 25 & 0.140 & 0.147 & 0.141 & & & \\
\hline 50 & 0.089 & 0.091 & 0.088 & & & \\
\hline 100 & 0.128 & 0.134 & 0.130 & & & \\
\hline
\end{tabular}

D1 = Intra-day, D2 = inter- day variations and df = degree of freedom. 
Table 3. Robustness of the proposed method $(n=6)$

\begin{tabular}{lccccc}
\hline Parameters & Level & \multicolumn{1}{c}{$\mathrm{t}_{\mathrm{R}}$} & $\mathrm{K}^{\prime}$ & $\mathrm{T}$ & $\left(\mathrm{R}_{\mathrm{s}}\right)$ \\
\hline 2.6 & -0.2 & 3.4 & 4.5 & 1.41 & 2.37 \\
2.8 & 0 & 3.8 & 4.3 & 1.43 & 2.36 \\
3.0 & 0.2 & 4.0 & 4.2 & 1.47 & 2.32 \\
\hline \multicolumn{5}{c}{ B: flow rate $\left(\mathrm{mL} \mathrm{min}^{-1}\right)$} \\
\hline 1.2 & -0.3 & 4.0 & 4.1 & 1.46 & 2.32 \\
1.5 & 0 & 3.8 & 4.3 & 1.43 & 2.36 \\
1.8 & 0.3 & 3.5 & 4.5 & 1.41 & 2.37 \\
\hline 85 & C: percentage of methanol in mobile phase (v/v/v) \\
90 & -5 & 3.5 & 4.7 & 1.42 & 2.39 \\
95 & 0 & 3.8 & 4.3 & 1.43 & 2.36 \\
\hline
\end{tabular}

$\mathrm{t}_{\mathrm{R}}=$ retention time, $\mathrm{K}^{\prime}=$ capacity factors, $\mathrm{N}=$ theoretical plates, $\mathrm{T}=$ tailing factor and $\mathrm{R}_{\mathrm{s}}=$ resolution.

chemistry. The action of many drugs is dependent on the coordination with metal ions, or/and the inhibition on the formation of metalloenzymes. ${ }^{23}$ The transition metals are integral part of an organic structure performing a vital function in the organism during the biological process of drug utilization in the body. The reduction of metals below certain limit results consistently in a reduction of physiologically important function. ${ }^{24}$ Although, the absorption of quinolone drugs is lowered when they are consumed simultaneously with multivitamins, magnesium or aluminium containing antacids and others bivalent cations. The proposed mechanism of the interaction is chelation between the 4-oxo and adjacent carboxyl group of quinolone and metal cations. Since these functional groups are required for antibacterial activity, it could be anticipated that all of the quinolones could be interacting with metal ions. Literature survey assembled a number of different complexation of quinolones. Efthimiadou et al..$^{25}$ discovered ciprofloxacin, cinoxacin, norfloxacin and nalidixic acid complexation with $\mathrm{VO}^{2+}, \mathrm{Mn}^{2+}$, $\mathrm{Fe}^{3+}, \mathrm{Co}^{2+}, \mathrm{Ni}^{2+}, \mathrm{Zn}^{2+}, \mathrm{MoO}^{2+}, \mathrm{Cd}^{2+}$ and $\mathrm{UO}^{2+}$, vanadyl complex with enrofloxacin and copper complexe with sparfloxacin. ${ }^{26}$ Skyrianou and co-workers ${ }^{27}$ reported nickel complex with sparfloxacin. Psomas et al. ${ }^{28}$ present ciprofloxacin interaction with $\mathrm{Mn}^{2+}, \mathrm{Fe}^{3+}, \mathrm{Co}^{2+}, \mathrm{Ni}^{2+}$ and $\mathrm{MoO}_{2}$. Alkaysi and co-workers ${ }^{29}$ published norfloxacin interaction with aluminum, magnesium and calcium. Iztok compiled interaction of 16 metals with eight quinolones. ${ }^{30}$ There have been reported complexes of ciprofloxacin with $\mathrm{V}(\mathrm{IV}) \mathrm{O}^{2+}, \mathrm{Fe}(\mathrm{III})^{31}$ and two complexes of norfloxacin with $\mathrm{Zn}(\mathrm{II}){ }^{32}$

In this paper, we also present application of our developed method by performing in vitro interaction of
GMFX with different essential, trace elements and heavy metals. The interaction of moxifloxacin was carried out at $37{ }^{\circ} \mathrm{C}$ for $30 \mathrm{~min}$ at simulated gastric juice and buffers of $\mathrm{pH}$ 4.0, 7.4 and 9.0. Complex formation of gemifloxacin with metals was shown by a considerable decrease in AUC and a drift in retention time.

\section{Interaction of GMFX with essential and trace metals}

Almost all metals were interacting with gemifloxacin in simulated gastric juice and buffers of $\mathrm{pH} 4.0,7.4$ and 9.0. All the metals show good interaction with gemifloxacin at every $\mathrm{pH}$. Availability of gemifloxacin with $\mathrm{Mg}, \mathrm{Mn}, \mathrm{Fe}$ and $\mathrm{Cu}$ was decreased to $\pm 38.74 \%$, while with $\mathrm{Ca}, \mathrm{Co}$ and $\mathrm{Cd}$ percentage decrease was found to be \pm 46.31 . Decrease in availability of gemifloxacin with $\mathrm{Cr}$ and $\mathrm{Ni}$ was $\pm 51.00 \%$, whereas with $\mathrm{Zn}$ it was $26.81 \%$. The $\%$ availability of gemifloxacin with $\mathrm{Ca}, \mathrm{Cr}$, $\mathrm{Fe}, \mathrm{Co}, \mathrm{Mn}, \mathrm{Ni}$ and $\mathrm{Cu}$ was decreased to 61.92-47.06 while with $\mathrm{Zn}$ and $\mathrm{Cd} \pm 75.81$ and $\mathrm{Mg}$ shows no significant interaction at $\mathrm{pH}$ 4.0. Availability of gemifloxacin with $\mathrm{Co}, \mathrm{Fe}, \mathrm{Cr}$ and $\mathrm{Mn}$ was up to $83.63-98.23 \%$. While with $\mathrm{Ni}, \mathrm{Mg}, \mathrm{Zn}, \mathrm{Ca}$ and $\mathrm{Cu}$ 50.11-66.76\% at $\mathrm{pH} 7.4$ and 9.0, availability of gemifloxacin with all metals was significant in the range of $53.8-61.52 \%$. The results of interaction are shown in Table 4.

Table 4. Percentage recovery of gemifloxacin with essential and trace elements

\begin{tabular}{lcccc}
\hline GMFX + Metal & pH 1.0 & pH 4.0 & pH 7.4 & pH 9.0 \\
\hline GMFX + Mg & 39.75 & 92.80 & 50.49 & 55.00 \\
GMFX + Ca & 41.22 & 55.36 & 64.10 & 58.45 \\
GMFX + Cr & 51.91 & 61.92 & 89.28 & 53.80 \\
GMFX + Mn & 38.74 & 54.03 & 98.23 & 61.52 \\
GMFX + Fe & 38.56 & 65.52 & 84.39 & 56.50 \\
GMFX + Co & 46.31 & 63.98 & 83.63 & 57.19 \\
GMFX + Ni & 51.04 & 68.39 & 50.11 & 58.25 \\
GMFX + Cu & 36.60 & 47.06 & 66.76 & 64.80 \\
GMFX + Zn & 26.81 & 75.06 & 54.59 & 60.34 \\
GMFX + Cd & 47.74 & 76.57 & 90.57 & 58.45 \\
\hline \% recovery of gemifloxacin with heavy metals & & \\
\hline GMFX + Metal & pH 1.0 & pH 4.0 & $\mathrm{pH} \mathrm{7.4}$ & $\mathrm{pH} \mathrm{9.0}$ \\
GMFX + Pb & 50.11 & 63.31 & 74.05 & 64.19 \\
GMFX + Ar & 57.84 & 52.19 & 85.84 & 68.64 \\
GMFX + Ag & 43.36 & 64.05 & 73.53 & 63.24 \\
\hline
\end{tabular}

\section{Interaction of GMFX with heavy metals}

Almost every heavy metal interacts with GMFX at selected pH (Table 4). Percentage availability of GMFX with heavy metals at all $\mathrm{pH}$ was in between $43.36-85.84 \%$ 
which suggests significant interaction among gemifloxacin and heavy metals.

\section{Conclusion}

The proposed HPLC method is simple, isocratic, rapid, specific, accurate and precise for determination of GMFX in bulk, pharmaceutical dosage formulation and human serum has been developed for the first time. Hence, it can be recommended for the routine quality control and evaluation of clinical data of gemifloxacin.

\section{Acknowledgement}

The authors wish to thanks Higher Education Commission (H.E.C) Pakistan for their financial support.

\section{References}

1. Oh, J. I.; Paek, M. J.; Ahn, M. Y.; Kim, C. Y.; Hong, C. Y.; Kim, I. C.; Kwak, J. H.; Antimicrob. Agents Chemother. 1996, 40, 1564.

2. Johnson, D. M.; Jones, R. N.; Erwin, M. E.; Diagn. Micr. Infec. Dis. 1999, 33, 87.

3 Berry, V.; Page, R.; Satterfield, J.; Singley, C.; Straub, R.; Woodnutt, G.; J. Antimicrob. Chemother. 2000, 45, 79.

4. Hardy, D.; Amsterdam, D.; Mandell, L.; Rotstein, C.; Antimicrob. Agents. Chemother. 1999, 44, 802.

5. Serkan, O.; Ther. Clin. Risk Manag. 2007, 3, 441.

6. Hannan, P.; Woodnutt, G.; Antimicrob. Agents Chemother. 2000, 45, 367.

7. Ann, A.; Elizabeth, B.; Marika, V.; Stuart, O.; Martin, J.; Christopher, W.; Ae-Jin, C.; Youn, S. C.; In-Chull, K.; Antimicrob. Agents Chemother. 2001, 45, 540.

8. Cristian, J.; Mark, G.; Int. J. Chron. Obstruct. Pulmon. Dis. 2009, 4, 291.

9. Doyle, E.; Fowles, S. E.; Mc Donnell, D. F.; Carthy, M.; White, S. A.; J. Chromatogr. B. 2000, 746, 191.

10. Ramji, J. V.; Austin, N. E.; Boyle, G. W.; Chalker, M. H.; Duncan, G.; Fairless, A. J.; Hollis, F. J.; Mc-Donnell, D. F.; Musick, T. J.; Shardlow, P. C.; Drug Metab. Dispos. 2001, 29 , 435.

11. Seung, I. C.; Jiyeon, S.; Min, S. K.; Yong, K. K.; Doo, S. C.; J. Chromatogr. A. 2004, 1055, 241.
12. Hee, J. C.; Hwan, S. C.; Sang, C. H.; Myung, H. H.; J. Sep. Sci. 2009, 32, 536.

13. Eun, S. K.; Yoo-Mo, K.; Doo, S. C.; J. Chromatogr. 2004, 1045, 119.

14. Myung, H. H.; Sang, C. H.; Yoon, J. C.; Jong, S. J.; Wonjae, L.; Biomed. Chromatogr. 2002, 16, 356.

15. Marothu, V. K.; Dannana, G. S.; E-J. Chem. 2008, 5, 515.

16. Barbosa, J.; Marquis, I.; Fonrodona, G.; Barth, D.; Bergs, R.; Anal. Chim. Acta 1997, 347, 385.

17. ICH - International Conference on Hormonisation of Technical Requirements for Registration of Pharmaceuticals for Human Use, Q2(R 1), Validation of Analytical Procedures, Methodology, 1996, London, Complementary Guideline on Methodology incorporated in November 2005.

18. The United States Pharmacopeia, USP 28, The United States Pharmacopeial Convention, Rockville, 2005, pp. 2748-2751.

19. Association Official Analytical Chemists; Official Methods of Analysis of $A O A C$, vol. 1, 17 $7^{\text {th }}$ ed., AOAC International: Gaithersburg, 2002, p. 20.

20. Shabir, G. A.; J. Chromatogr. A. 2003, 987, 57.

21. Ermer, J.; J. Pharm. Biomed. Anal. 2001, 24, 755.

22. The United States Pharmacopeia, USP 30/NF 25, National Formulary, <1225> Validation of Compendial Methods, Rockville, 2007, p. 549.

23. Efthimiadou, E. K.; Yiannis, S.; Katsaros, N.; Karaliota, A.; Psomas, G.; Polyhedron 2007, 26, 1148.

24. Mertz, W.; Biol. Trace. Elem. Res. 1998, 66, 185.

25. Efthimiadou, E. K.; Katsaros, N.; Karaliota, A.; Psomas, G.; Bioorg. Med. Chem. Lett. 2007, 17, 1238.

26. Efthimiadou, E. K.; Karaliota, A.; Psomas, G.; J. Inorg. Biochem. 2008, 102, 910.

27. Skyrianou, K. C.; Efthimiadou, E. K.; Psycharis, V.; Terzis, A.; Kessissoglou, D. P.; Psomas, G.; J. Inorg. Biochem. 2009, 103, 1617.

28. Psomas, G.; J. Inorg. Biochem. 2008, 102, 1798.

29. Alkaysi, H. N.; Abdel-Hay, M. H.; Salem, M. S.; Gharaibeh, A. M.; Na'was, T. E.; Int. J. Pharma. 1992, 87, 73.

30. Iztok, T.; Coordin. Chem. Rev. 2002, 232, 27.

31. Steven, C.; Wallis, R. G.; Lawrence, R. G.; Bruce, G.; Charles, T.; Hambley, W.; Polyhedron 1995, 14, 2835.

32. Zhen, F. C.; Ren, G. X.; Jing, Z.; Xue, T. C.; Zi, L. X.; Xiao, Z. Y.; Inorg. Chem. 2001, 40, 4075.

Submitted: November 22, 2010

Published online: February 1, 2011 